\title{
FOOD AS A TOURISM COMPETITIVENESS FACTOR OF JABLANICA DISTRICT IN SERBIA
}

\author{
Predrag Stamenković' ${ }^{1}$ Lukrecija Djeri ${ }^{2}$
}

\begin{abstract}
Summary
Jablanica district represents mainly rural and economically underdeveloped part of Serbia. However, it is characterized by a favorable geographical position, great natural and cultural resources, which are not yet adequately valorized and presented on the tourism market. This paper, with appropriate statistical procedures, processes both, importance and performance factors of tourist destination, and identifies food as a factor of primary importance for improvement of tourism competitiveness in the Jablanica district. The results of this study could be of great importance for tourism managers in the destination, as well as for local government authorities, to understand better the importance of the identified competitiveness factors, and provide them a good starting point for tourism development.
\end{abstract}

Key words: competitiveness factors, IPA, local development, Jablanica District.

JEL: $C 38, Q 18, L 83$

\section{Introduction}

Nowdays, tourism is one of the sectors with the highest growth, seen by many countries, especially their underdeveloped regions, as a sector for gaining quick short-term benefits. In order to adapt to dynamic market conditions, countries base their development on tourism, thereby they are permanently focused on competitiveness improvement of their tourist destinations. The key issue becomes: how destination develops, maintains and improves its competitiveness in the face of constantly growing international competition (Dwyer, Kim, 2003; Crouch, 2010; Croes, 2010). There is a large number of attributes and factors that affect tourism destinations competitiveness, and that set competitiveness as a primary issue.

1 Predrag Stamenković M.Sc., Ph.D. candidate, University of Novi Sad, Faculty of Sciences, Department of Geography, Tourism and Hotel Management, Dositeja Obradovića Square no.3, 21000 Novi Sad, Serbia, Phone: +381 6373317 53, E-mail: leskopex@yahoo.com

2 Lukrecija Djeri (corresponding author), Ph.D., Associate Professor, University of Novi Sad, Faculty of Sciences, Department of Geography, Tourism and Hotel Management, Dositeja Obradovića Square no.3, 21000 Novi Sad, Serbia, Phone: +381 641501310 , E-mail: djerilukrecija@gmail.com

EP 2016 (63) 4 (1253-1263) 
Countries, especially their underdeveloped districts, are often at loss in understanding the nature and determinants of tourism destinations competitiveness, despite their need for a policy of strengthening their relative competitive position. The essence of this problem is the lack of knowledge and understanding of the relevant factors affecting destinations competitiveness, on the extent to which of these factors affect competitiveness, as well as the failure to prioritize the factors that require resources optimization to mitigate the competitiveness disadvantages and reinforcing the relative strength. Since the 1990s, research efforts have been directed towards the development of theoretical and conceptual basis for the analysis of the tourism competitiveness (Crouch, Ritchie, 1999; Dwyer, Kim, 2003; Heath, 2003; Ritchie, Crouch, 2003).

Author Azzopardi (2011) points out that, these studies are a continuation of previous research on the destinations attractiveness, tourism competitiveness strategies and general market competitiveness. These models emphasize the view that the competitiveness of tourist destinations cannot be understood or measured on the basis of several determinants and in response, they propose several potential factors that could affect the competitiveness. Several studies have attempted to apply these models in whole or in part to certain destinations, or to elaborate on their measurement (Gomezelj, Mihalic, 2008; Ritchie, Crouch, 2010; Armenski et al., 2011).

In domestic literature analysis of competitiveness factors was performed on the level of individual city destinations (Bolić, 2013; Milenković, Bošković, 2014), on regional level (Djeri et al., 2014), as on the national level (Zečević, 2011; Popesku, Pavlović, 2013; Ubavić, 2015), but not on the level of district as a tourist destination.

In that regard, there is a need for this kind of research, because tourism is recognized as one of the key elements for development of districts with underdeveloped tourism infrastructure, but with preserved natural and anthropogenic resources, such as the case of Jablanica district. In order for tourism to provide progressive development and contribution to the diversification and promotion of the regional economy, employment growth and the reduction of depopulation, it is necessary to determine which factors can improve tourism competitiveness in Jablanica District.

\section{Methodology and data sources}

For the purposes of testing the perception of tourists on competitiveness factors in destination of Jablanica District, questionnaire, created by the author Geng-Qing Chi (2005) was used. This questionnaire was designed based on extensive literature review of tourist destinations competitiveness models, individuals participating in the focus groups at Eureka Springs, travel brochures, etc. The selected 32 destination attributes were rated on a two parallel (importance; performance), 5-point Likert type scales, where 1= Least Important/Strongly Disagree and 5= Most Important/Strongly Agree. The questionnaire was prepared in two languages: Serbian and English.

Research data were obtained by direct research on the basis of a simple random sample. Tourists who visited Jablanica district during the five research months in 2013 (May to 
September) made the sampling target population. The total of 378 validly completed questionnaires was collected. Statistical processing and data analysis was conducted after collecting the questionnaires results. In that purpose, statistical software IBM SPSS 20.0 (Statistical Package for the Social Sciences) was used.

Exploratory factor analysis (EFA) was performed, downsizing the number of research attributes to a smaller number of factors, with the aim of more concise data processing. Two tests of factor analysis feasibility were applied: Bartlett's test of sphericity, whose significance should be at a level of Bartlett $p<0.05$ (Bartlett, 1954); and Kaiser-Meyer-Olkin - KMO indicator, whose values are within the range of 0 to 1 , so the value of $0.6(\mathrm{KMO} \geq 0.6)$ is recommended as the minimum amount acceptable for good factor analysis.

In order to verify the validity of the measuring instrument, we used Cronbach's Alpha Reliability Coefficient $(\alpha)$. This value of this coefficient should be higher than 0.7 (DeVellis, 2003).Tourist satisfaction with performance of tourism products and services in the Jablanica District, was examined with the Importance and Performance Analysis (IPA).

In order to verify the competitiveness of isolated factors, following research hypotheses were created:

H1 - Among the selected destination attributes, food stands out as one of the Jablanica district competitiveness factors.

H2 - Among the isolated competitiveness factors, Food factor has primary importance for tourists, when choosing tourism destination Jablanica District;

H3 - Within the Food factor, tourists in Jablanica District, give the greatest importance to the attribute of food quality.

\section{Results and discussion}

In order to analyze the perception of tourists satisfaction with destination competitiveness attributes of Jablanica district, exploratory Factor analysis (EFA) was applied, with the Principal components analysis extraction method (PCA) and Varimax rotation of factors. Extracted competitiveness attributes were grouped into seven factors.

Principal component analysis (PCA) was carried out on 32 identified attributes, which were used to evaluate the degree of tourist satisfaction. Results of Kaiser-Meyer-Olkin measure, indicated good factors matrix, with the values of 0.881 which exceeds the recommended level of 0.60 (Kaiser, 1974). Bartlett's test of sphericity showed us statistically significant value $(\mathrm{p}=0.000)$, so that validity of applying exploratory Factor analysis was confirmed (Bartlett, 1954) (Table 1).

Extraction of factors and defining dimension was performed with several criteria: the characteristic value (eigenvalue), percent of Variance, Cronbach's alpha coefficient, communalities extracted of individual motives, and factors loadings with their structure. All extracted factors had the characteristic values (eigenvalue), greater than 1 . In order to provide an appropriate factor solution, factor structures that explained minimum $60 \%$ of the total 
variance were taken into consideration.

Seven factors with characteristic values (eigenvalues), over 1, were discovered by analyzing the principal components (PCA), with total Variance of $65.79 \%$. Communality values were calculated in the range of 0.407 to 0.794 , which confirmed good Factor matrix.

Table 1. KMO and Bartlett test of sphericity - factors of competitiveness (tourists)

\begin{tabular}{|l|l|r|}
\hline \multicolumn{2}{|l|}{ Kaiser-Meyer-Olkin Measure of Sampling Adequacy. } & $\mathbf{. 8 8 1}$ \\
\hline \multirow{3}{*}{ Bartlett's Test of Sphericity } & Approx. Chi-Square & $7,256.948$ \\
\cline { 2 - 3 } & df & 528 \\
\cline { 2 - 3 } & Sig. & .000 \\
\hline
\end{tabular}

Source: authors, based on research

Based on the items that constitute the seven factor solution, factors were appointed to: F1 Accommodation, F2 - Food, F3 - Environment, F4 - Accessibility, F5 - Activities and events, F6 - Shopping and F7 - Attractions. For the seven factor solution proposed by this research, Cronbach's alpha coefficient is: $\alpha=0.817$ which suggests an adequate internal consistency of isolated factors.

Table 2. EFA - seven factor solution of Jablanica district competitiveness attributes

\begin{tabular}{|c|c|c|c|c|c|}
\hline & $\begin{array}{l}\text { Eigen } \\
\text { Value }\end{array}$ & $\begin{array}{l}\text { Variance } \\
\text { Explained }\end{array}$ & $\begin{array}{l}\text { Cronbach's } \\
\text { alfa }\end{array}$ & $\begin{array}{c}\text { Factor } \\
\text { Loadings }\end{array}$ & Communalities \\
\hline F1 - Accommodation & 10.468 & 31.722 & 0.896 & & \\
\hline $\begin{array}{l}\text { Quality and cleanliness of } \\
\text { accommodation }\end{array}$ & & & & 0.825 & 0.794 \\
\hline Services at accommodation & & & & 0.797 & 0.755 \\
\hline $\begin{array}{l}\text { Uniqueness of } \\
\text { accommodation }\end{array}$ & & & & 0.677 & 0.619 \\
\hline Diversity of accommodation & & & & 0.666 & 0.696 \\
\hline Price of accommodation & & & & 0.654 & 0.621 \\
\hline F2 - Food & 2.951 & 8.943 & 0.875 & & \\
\hline Meal plan & & & & 0.845 & 0.761 \\
\hline Service in restaurants & & & & 0.809 & 0.738 \\
\hline Diversity of cuisine & & & & 0.746 & 0.652 \\
\hline Food quality & & & & 0.746 & 0.683 \\
\hline Reasonable prices & & & & 0.542 & 0.544 \\
\hline F3 - Environment & 2.214 & 6.709 & 0.834 & & \\
\hline Cleanliness & & & & 0.759 & 0.627 \\
\hline Safety and security & & & & 0.711 & 0.667 \\
\hline $\begin{array}{l}\text { Peaceful and restful } \\
\text { atmosphere }\end{array}$ & & & & 0.686 & 0.684 \\
\hline
\end{tabular}




\begin{tabular}{|c|c|c|c|c|c|}
\hline $\begin{array}{l}\text { The importance of } \\
\text { environment }\end{array}$ & & & & 0.664 & 0.701 \\
\hline Friendliness of local people & & & & 0.622 & 0.659 \\
\hline F4 - Accessibility & 1.822 & 5.522 & 0.837 & & \\
\hline $\begin{array}{l}\text { Availability of travel } \\
\text { information }\end{array}$ & & & & 0.758 & 0.724 \\
\hline Level of accessibility & & & & 0.700 & 0.692 \\
\hline $\begin{array}{l}\text { Helpfulness of welcome } \\
\text { center }\end{array}$ & & & & 0.699 & 0.611 \\
\hline $\begin{array}{l}\text { Availability of transport / taxi } \\
\text { service }\end{array}$ & & & & 0.642 & 0.634 \\
\hline Availability of local parking & & & & 0.519 & 0.407 \\
\hline F5 - Activities and events & 1.515 & 4.590 & 0.533 & & \\
\hline $\begin{array}{l}\text { Variety of spa/massage/ } \\
\text { healing options }\end{array}$ & & & & 0.805 & 0.728 \\
\hline Variety of outdoor recreation & & & & 0.699 & 0.664 \\
\hline $\begin{array}{l}\text { Variety of evening } \\
\text { entertainment }\end{array}$ & & & & 0.666 & 0.584 \\
\hline $\begin{array}{l}\text { Reasonable price for } \\
\text { activities and events }\end{array}$ & & & & 0.546 & 0.557 \\
\hline $\begin{array}{l}\text { Variety of special events/ } \\
\text { festivals }\end{array}$ & & & & 0.311 & 0.140 \\
\hline F6 - Shopping & 1.393 & 4.223 & 0.879 & & \\
\hline Friendliness of service & & & & 0.839 & 0.793 \\
\hline Quality of merchandise & & & & 0.762 & 0.733 \\
\hline $\begin{array}{l}\text { Reasonable price of } \\
\text { merchandise }\end{array}$ & & & & 0.724 & 0.680 \\
\hline Variety of shops & & & & 0.580 & 0.654 \\
\hline F7 - Attractions & 1.346 & 4.079 & 0.867 & & \\
\hline Variety of natural attractions & & & & 0.810 & 0.766 \\
\hline Variety of cultural options & & & & 0.763 & 0.703 \\
\hline $\begin{array}{l}\text { Variety of historic/cultural } \\
\text { sites }\end{array}$ & & & & 0.710 & 0.730 \\
\hline $\begin{array}{l}\text { Reasonable price for } \\
\text { sightseeing }\end{array}$ & & & & 0.661 & 0.710 \\
\hline
\end{tabular}

Source: authors, based on research

Based on the results of factor analysis, we conclude that Food factor (F2) stands out as Jablanica district competitiveness factor, which confirms hypothesis H1. Within the Food factor (F2), following variables are grouped: meal plan; service in restaurants; diversity of cuisine; food quality; reasonable prices. This factor explains $8.94 \%$ of the total Variance of and the characteristic value (eigenvalue), amounts 2.95. Cronbach's alpha coefficient has a value of $\alpha=0.817$, which suggests an adequate internal consistency of this factor.

With the objective of determining tourist satisfaction with performances of tourism products and services in the Jablanica District tourist destination, the analysis of the Importance and 
Performance (IPA) was conducted. Achieved overall Importance and Performance mean values of extracted factors, were calculated for the whole sample and given in Table 3.

Table 3. IPA mean scores - competitiveness factors of Jablanica district

\begin{tabular}{|l|c|c|c|}
\hline \multicolumn{1}{|c|}{ Destination factors } & Importance & Performance & Mean dif. \\
\hline F1 - Accommodation & 3.94 & 3.74 & -0.20 \\
\hline F2 - Food & $\mathbf{4 . 2 5}$ & $\mathbf{4 . 1 2}$ & $\mathbf{- 0 . 1 3}$ \\
\hline F3 - Environment & 4.20 & 3.89 & -0.31 \\
\hline F4-Accessibility & 4.02 & 3.66 & -0.36 \\
\hline F5 - Activities and events & 3.94 & 3.66 & -0.28 \\
\hline F6- Shopping & 3.94 & 3.74 & -0.20 \\
\hline F7 - Attractions & 4.04 & 3.83 & -0.21 \\
\hline Grand Mean & $\mathbf{4 . 0 6}$ & $\mathbf{3 . 8 1}$ & $\mathbf{- 0 . 2 5}$ \\
\hline
\end{tabular}

Source: authors, based on research

These values were used as coordinates to create IPA matrix. The overall average of Importance values have been inserted to the vertical $(y)$ axis, while the overall Performance values average, of the evaluated competitiveness factors, were inserted on the horizontal $(x)$ axis. As a point of intersection of $(x)$ and $(y)$ axis, of the IPA matrix coordinating system, overall average values of all components of Importance (4.06) and Performance (3.81), were used, which produced four quadrants.

Figure 1. Importance - Performance Analysis grid - results

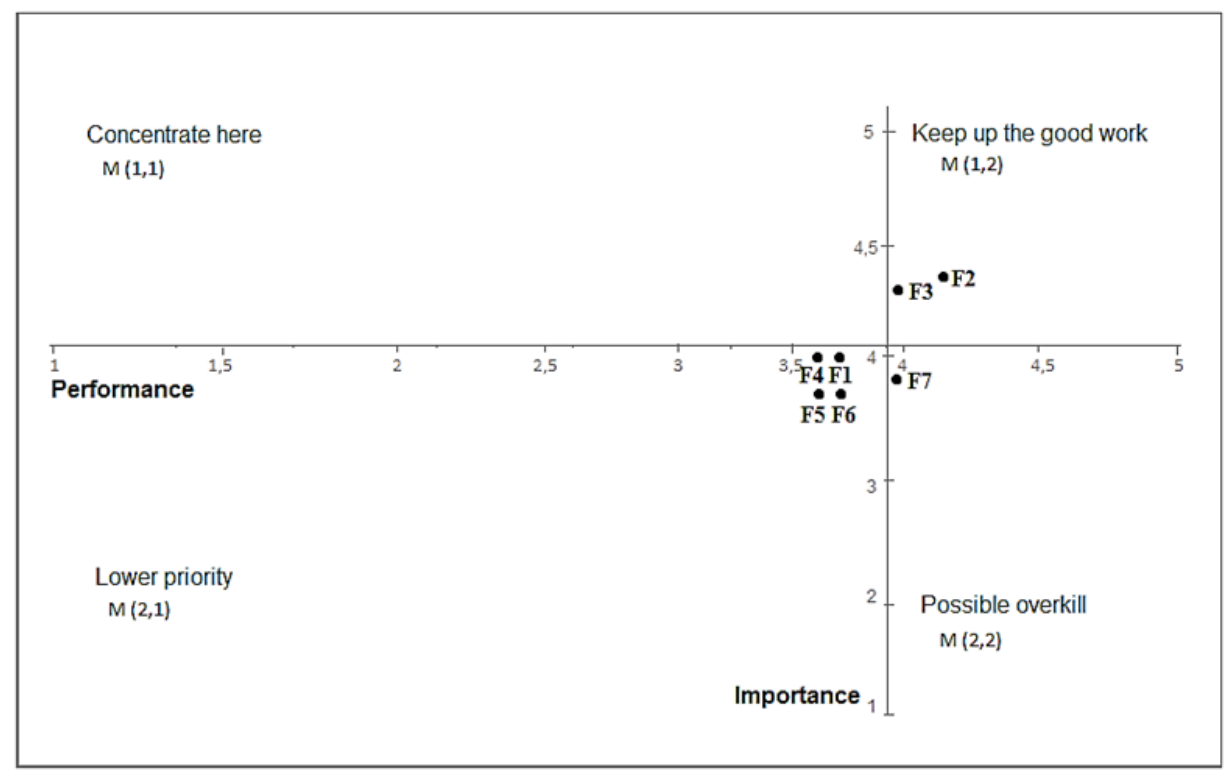

Source: Author's illustration

Components that are positioned in the upper left quadrant $\mathrm{M}(1.1)$ are evaluated as very important, but the level of performance is rated below average (Concentrate here). Components 
in the upper right quadrant $\mathrm{M}(1.2)$ are rated as very important and the level of performance is above average (Keep up the good work). Components in the lower left quadrant M (2.1) are considered to be less important and the level of performance is below average (Low priority). Finally, the components in the lower right quadrant $M(2.2)$ are estimated above average on the scale of performance, but also estimated below average on the scale of importance (Possible overkill) (Martilla, James, 1977).

As shown in Figure 1. Food factor (performance: 4.12; importance: 4.25) is located in the field of $\mathrm{M}$ (1.2) and rated as very important for the respondents with above-average performance values. On this basis, we can conclude that Food is the factor which has a primary importance for tourists, when choosing tourism destination Jablanica District. This result confirms hypothesis $\mathbf{H 2}$. After the Food factor, tourists rated Environment, also like a very important factor with good performance values, positioning it in same field of $\mathrm{M}(1.2)$. Strategic management direction for these factors is, keep up the good work.

When we observe other extracted factors, we can conclude that factor Attractions is at satisfactory level, positioned in the field M (2.2), which means that tourists estimated it above average on a scale of performance, while, on the scale of importance, it was rated below average. This factor therefore has no great importance for the tourists, so it is not recommended to invest in innovation and improvement of its performance. The factors of accommodation, accessibility, activities and events, shopping are positioned in the field of low priority $\mathrm{M}$ (2.1) where are considered to be less important and the level of satisfaction is below average.

Since it was confirmed that among the isolated competitiveness factors, Food factor has a primary importance for tourists, when choosing tourism destination Jablanica District, we wanted to determine which attribute in the context of this factor has the greatest importance for tourists.

Achieved overall Importance and Performance mean values of extracted attributes within Food factor, were calculated for the whole sample and given in Table 4.

Table 4. IPA mean scores - competitiveness factors of Jablanica district

\begin{tabular}{|l|c|c|c|}
\hline F2 - Food & Importance & Performance & Mean dif. \\
\hline F2a - Meal plan & 4.25 & 4.14 & -0.11 \\
\hline F2b - Service in restaurants & 4.26 & 4.15 & -0.11 \\
\hline F2c - Diversity of cuisine & 4.17 & 4.08 & -0.09 \\
\hline F2d - Food quality & 4.31 & 4.13 & -0.18 \\
\hline F2e - Reasonable prices & 4.26 & 4.10 & -0.16 \\
\hline Grand mean & $\mathbf{4 . 2 5}$ & $\mathbf{4 . 1 2}$ & $\mathbf{- 0 . 1 3}$ \\
\hline
\end{tabular}

Source: authors, based on research

The food quality attribute (performance: 4.13; importance: 4.31 ) is positioned in the field Keep up the good work M (1.2) indicating that it has a great importance for the respondents, while the level of satisfaction with this attribute is above average so we can conclude that the hypothesis $\mathrm{H3}$ is confirmed.

EP 2016 (63) 4 (1253-1263) 
Besides the food quality, in this field are also located, attributes of service in restaurants and diversity of cuisine, as shown in Figure 2. In order to maintain the current favorable trend, certain investments in this field are needed for sure, however, there is no need for the urgent managerial action in order to improve the performance of the attributes, because the tourists are satisfied with them.

Figure 2. Importance - Performance Analysis of food factor - attributes

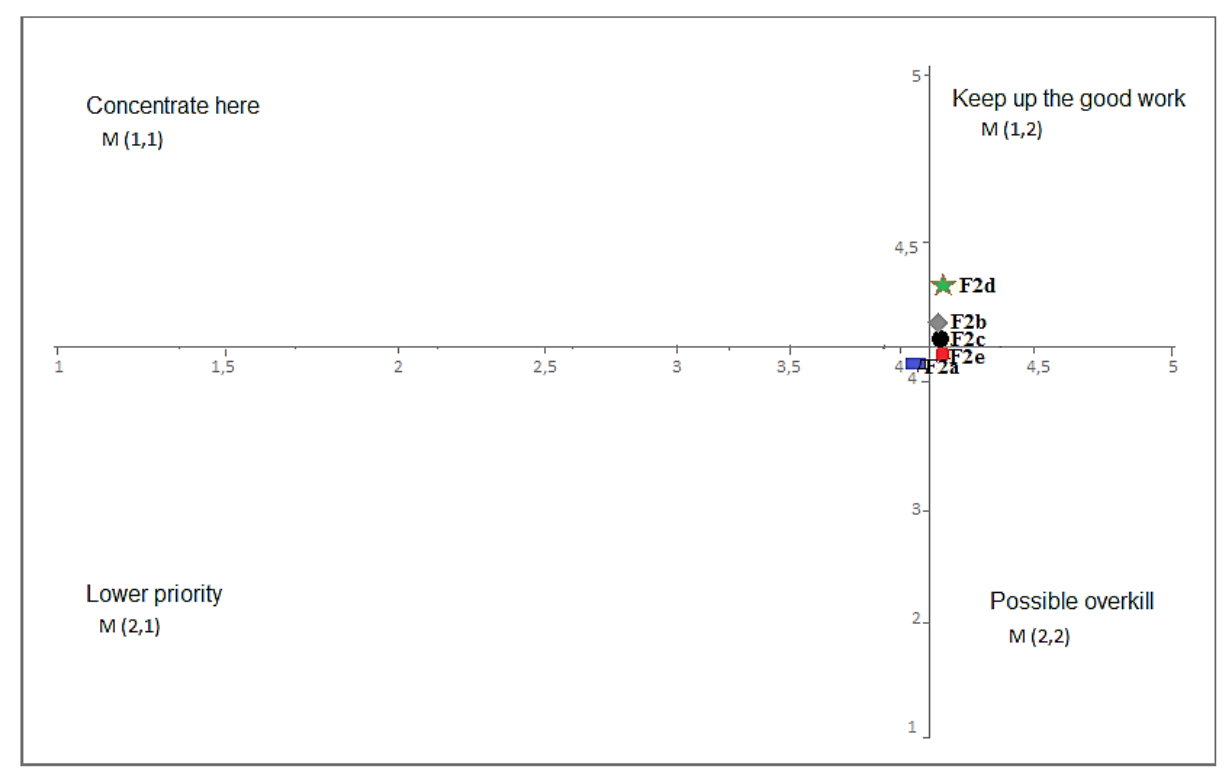

Source: Author's illustration

The attribute food price, is at satisfactory level, located in the field M (2.2). Jablanica Distrist is characterized by low prices, especially food prices, so tourists who visited this destination, were pre-prepared for this kind of situation, so they did not give a great importance to the attribute of price. This result suggests tourism managers in Jablanica district that food price attribute does not require additional investments (Possible overkill).

The meal plan attribute is located in the field of low priority $\mathrm{M}$ (2.1) where is considered to be less important and the tourists level of satisfaction is below average, and therefore does not require attention of the holders of tourism policy in the district, in terms of investing in the improvement of its performance.

\section{Conclusion}

Jablanica district is located in the south of the Republic of Serbia. It is characterized by extremely favorable tourist and geographic position and proximity to large urban emitting centers (Sofia, Skopje, Nis, Pristina and Vranje), which makes a great potential for tourism development. By field research and insight into natural and social tourist attractions, it can be concluded that Jablanica district has exceptional resource base of tourism development. Valorization of existing tourist products, as well as those tourist products for which there 
is adequate resource base, is the first step in the formation of competitive tourism package products of Jablanica district.

In this paper we found that the food is the factor on which to base a competitive advantage of Jablanica district. This factor should have the function of prompter of general tourism development, and also to expand commercialization of its effects on other tourism products. This factor can achieve its market valorisation, best through some of the selective forms of tourism such as gastronomic, rural and manifestation tourism.

Gastronomical offer may have a significant role in the promotion of these forms of tourism in Jablanica District. It is necessary to attract tourists with better promotion and whenever possible, offer them degustation of autochthonous gastronomic products. This kind of experience could provoke desire of re-visiting the region among tourists, for the enjoyment in local food.

One of the most important segments in the gastronomy sector, could be locally produced agricultural products. Such products, in many countries, their regions and cities, occupy an enviable percentage of the share in the tourism consumption. The central place of Jablanica district is occupied by Leskovac basin, which has a great importance for the development of agriculture, as it is characterized by a very favorable climate and great soil fertility. Tradition of this region is the cultivation of vegetable products which have a high usage in the hospitality industry (peppers, tomatoes, potatoes and cabbage). Also, an important segment of this region agriculture, presents fruit production, which is dominated by cherry, strawberry, plum and raspberry, whose products also include the possibility of a wide market placements through tourism.

\section{Literature}

1. Armenski,T., Gomazelj, D., Djurdjev, B., Čurčić, N., Dragin, A. (2011): Tourism destination competitiveness - Between two flags. Economic Research, vol. 25, no. 2, pp. 485-502.

2. Azzopardi, E. (2011). The international competitiveness of Malta as a tourist destination, (DBA Dissertation), Robert Gordon University, Aberdeen.

3. Bartlet, M. (1954): A note on the multiplying factors for various chi square approximations. Journal of the Royal Statistical Society, vol. 16, Series B, pp. 296298.

4. Bolić, M. (2013): Perspektive razvoja grada Beograda kao destinacije, (Master rad), Univerzitet Singidunum, Beograd.

5. Croes, R. (2010): Measuring and explaining competitiveness in the context of small island destinations. Journal of Travel Research, vol. 20, no. 10, pp. 1-12.

6. Crouch, G., Ritchie, J. (1999): Tourism, competitiveness and societal prosperity. Journal of Business Research, vol. 44, pp. 137-152.

7. Croes, R. (2010): Measuring and explaining competitiveness in the context of small island destinations. Journal of Travel Research, vol. 20, no. 10, pp. 1-12. 
8. DeVellis, R. F. (2003): Scale development: Theory and application (ISBN: 9781412980449). Sage, Thousand Oaks.

9. Djeri, L., Armenski, T., Jovanović, T., Dragin, A. (2014): How income influences the choice of Tourism Destination? Acta Oeconomica, vol. 64, no. 2, pp. 219-237.

10. Dwyer, L., Kim, C. (2003): Destination competitiveness: determinants and indicators. Current Issues in Tourism, vol. 6, no. 5, pp. 369-414.

11. Geng-Qing Chi, C. (2005): A Study of Developing Destination Loyalty Model, (Doctoral dissertation) Faculty of the Graduate College of the Oklahoma State University, Oklahoma.

12. Gomezelj, D., Mihalic, T. (2008): Destination competitiveness: applying different models, the case of Slovenia. Tourism Management, vol. 29, pp. 294-307.

13. Heath, E. (2003): Towards a model to enhance competitiveness: a Southern African perspective. Journal of Hospitality and Tourism Management, vol. 10, no. 2, pp. 124-141.

14. Kaiser, H. (1974): An index of factorial simplicity. Psychometrika, vol. 39, pp. 3136.

15. Martilla, J., James, J. (1977). Importance-performance analysis. Journal of Marketing, vol. 41, no. 1, pp. 77-99.

16. Milenković, S., Bošković, N. (2012). Razvojne tendencije ekoturizma Srbije. Teme, vol. 36, no. 2, pp. 483-499.

17. Popesku J., Pavlović D. (2013): Konkurentnost Srbije kao turističke destinacije analiza odabranih ključnih pokazatelja. Marketing, vol. 44, no. 3, pp. 199-210.

18. Ritchie, B., Crouch, G. (2003): The competitive destination: a sustainable tourism perspective (ISBN: 0851996647). CABI Publishers, Wallingford.

19. Ritchie, B., Crouch, G. (2010): A Model of Destination Competitiveness/ Sustainability: Brazilian Perspectives, Revista de Administração Pública (RAP)/ Brazlian Public Administration Review, vol. 55, no. 5, pp. 1049-1066.

20. Ubavić, P. (2015): Kreiranje konkurentskog profila Srbije kao turističke destinacije. Škola biznisa, vol. 1, pp. 80-97.

21. Zečević, B. (2011): Koncepti konkurentnosti turističkih destinacija - značaj $i$ primenljivost na slučaju Srbije. Novi metodi menadžmenta i marketinga u podizanju konkurentnosti srpske privrede, Naučni skup, Palić. 


\title{
UTICAJ FAKTORA HRANA NA KONKURENTNOST TURIZMA JABLANIČKOG OKRUGA U SRBIJI
}

\section{Predrag Stamenkovic ${ }^{3}$, Lukrecija Djeri ${ }^{4}$}

\begin{abstract}
Rezime
Jablanički okrug predstavlja pretežno ruralni i ekonomski nerazvijeni deo Srbije. Međutim, okrug karakterišu, povoljan geografski položaj, bogatstvo u prirodnim i antropogenim resursima koji još uvek nisu na adekvatan način valorizovani i predstavljeni na turističkom tržištu. U ovom radu, se primenom analize važnosti $i$ performansi obrađuju faktori konkurentnosti turističke destinacije, $i$ ističe hrana kao faktor od primarnog značaja za unapređenje konkurentnosti turizma u Jablaničkom okrugu. Rezultati ovog istraživanja mogu biti od velike koristi turističkim menadžerima u destinaciji, kao i rukovodstvima jedinica lokalnih samouprava u okrugu, u cilju boljeg razumevanja značaja identifikovanih faktora konkurentnosti, čime bi im omogućili dobru polaznu osnovu za razvoj turizma.
\end{abstract}

Ključne reči: faktori konkurentnosti, analiza važnosti i performansi-IPA, lokalni razvoj, Jablanički okrug.

3 Master Predrag Stamenković, doktorand, Univerzitet u Novom Sadu, Prirodno-matematički fakultet, Departman za geografiju, turizam i hotelijerstvo, Trg Dositeja Obradovića br. 3, 21 000 Novi Sad, Srbija, Telefon: + 3816373317 53, E-mail: leskopex@yahoo.com

4 Vanredni profesor dr Lukrecija Djeri, Univerzitet u Novom Sadu, Prirodno-matematički fakultet, Departman za geografiju, turizam i hotelijerstvo, Trg Dositeja Obradovića br. 3, 21 000 Novi Sad, Srbija, Telefon: + 3816415013 10, E-mail: djerilukrecija@gmail.com 